6. Kuzmina, T. (2002). Kulturotvorcheskaja sreda kak faktor samorazvitija pedagogicheskogo kollektiva obrazovatelnogo uchrezhdenija [Culture environment as a factor of self-development of the teaching staff of an educational institution]. Candidate's thesis. 213 p. [in Russian].

7. Leonteva V.N. (2003). Kulturotvorcheskij process : osnovanija $i$ nachala [Cultural making process: the foundations and beginnings]. Kharkov, 216 p. [in Russian].

8. Semyonov, V.S. (1982). Kultura i razvitie cheloveka [Culture and human development]. Questions of philosophy. No.4, pp. 15-29. [in Russian].
9. Sungatullina, G.I. (2006). Razvitie kulturotvorcheskih kompetencij uchashhihsja v uslovijah sozdanija uchebnogo muzeja [The development of culture-making competence of students in the conditions of creation an educational museum]. Extended abstract of candidate's thesis. 26 p. [in Russian].

10. Fölsch, T. (2010). Kompetenzentwicklung und Demografie [Competence development and demography]. Dissertation on obtaining the academic degree of Doctor of Economics and Social Sciences (Dr. rer. Pol.). Kassel university press $\mathrm{GmbH}, 146$ p. [in German].

Стаття надійшла до редакції 15.04.2019

УДК 373.5.015.31:34

DOI:

Мар'яна Кащук, кандидат педагогічних наук доцент кафедри іноземних мов та культури фахового мовлення Львівського державного університету внутрішніх справ

\title{
ФОРМИ ПРАВОВОГО ВИХОВАННЯ УЧНІВСЬКОЇ МОЛОДІ (історичний аспект)
}

У статті розглянуто форми реалізації правового виховання старшокласників у другій половині ХX століття. Розкрито суть різноманітних форм правового виховання і охарактеризовано методику їх використання у діяльності загальноосвітньої школи у другій половині ХХ століття. Акиентовано увагу на таких формах правового виховання, як лекторії, кінолекторії, семінари, диспути, вечори запитань та відповідей, тематичні вечори тощч.

Ключові слова: форми правового виховання; старшокласники; лекторії; кінолекторії; семінари; диспути; вечори запитань та відповідей; тематичні вечори.

Jim. 7.

Maryana Kashchuk, Ph.D.(Pedagogy), Associate Professor of the Foreign Languages and Culture of Professional Speech Department Lviv State University of Internal Affairs

\section{FORMS OF LEGAL EDUCATION OF PUPILS (historical aspect)}

The forms of realization of legal education of senior pupils in the second half of the twentieth century are considered in the article. The essence of different forms of legal education is revealed and the methods of their application in the activity of secondary school are characterized. A special attention is paid to such forms of legal education as a cycle of lectures, a cycle of films, seminars, disputes, the evenings of questions and answers, topical evenings, etc. It is stated that the usage of a cycle of lectures as well as a cycle of films has become a necessary condition for successful realization of legal education increasing the level of motivation among pupils. They have been carried out according to a definite plan and organized due to the interests of senior pupils. Seminars and disputes have played an important role in spreading the legal knowledge. Such forms of legal education helped the pupils to exchange their knowledge in the field of law with each other. The evenings of questions and answers as well as topical evenings have contributed greatly to formation of legal culture of senior pupils. An excursion to different places was also an effective extracurricular form of legal education of senior pupils in the course of which they could apply their theoretical knowledge to practice. During such excursions the senior pupils studied the work of state bodies, enterprises, etc and learned how to satisfy physical and spiritual needs of the citizens. Furthermore, some special circles have been formed in many schools, and experienced lawyers carried out seminars and lectures, organized discussion of urgent issues, demonstrated some films pertaining to legal problems, etc. In their turn, the senior pupils worked on their reports, helped law enforcement workers with problematic pupils, 
organized some exhibitions and quiz. Therefore, all mentioned above has greatly contributed to the development of positive climate among pupils.

Keywords: means of legal education; senior pupils; a cycle of lectures; a cycle of films; seminars; disputes; evenings of questions and answers; topical evenings.

$\Pi$ остановка проблеми. Дослідження методичних аспектів організації роботи щодо правового виховання учнівської молоді, зокрема його форм, залишається актуальним завданням сучасної педагогічної науки. Історичний контекст нашої проблеми визначається потребою вивчення тих аспектів означеного процесу, які є маловідомими сьогодні. До того ж, позитивний історичний досвід може бути ефективно використаний у системі сучасного правового виховання учнів загальноосвітньої школи.

Аналіз основних досліджень та публікацій. Проблеми використання форм правового виховання учнівської молоді вивчаються у працях таких вчених: В. Найбіча, В. Оксамитного, М. Козюбри, А. Айзенберга, В. Головченка, Г. Давидова, А. Павлова, В. Альхіменка, М. Фіцули та багатьох інших.

Мета статті - проаналізувати різні форми, які використовувалися для реалізації правового виховання учнівської молоді у другій половині ХХ століття.

Виклад основного матеріалу. Різноманітність форм правового виховання у досліджуваний період сприяла результативності означеного процесу та його ефективності. До поширених форм належали зокрема постійнодіючі лекторії, які були розраховані на певну аудиторію, а саме старшокласників. Тут школярі мали змогуне лише прослухати певну інформацію у галузі права, але й одержували відповіді на питання, що їх хвилювали. I хоч такі форми роботи часто мали у своїй основі не зовсім добровільний характер, все ж гарантували кваліфіковану допомогу та фахову поінформованість школярам.

Вони мали відповідні назви: "Товариш підліток”, “Юний дзерджинець”, “Підліток і закон”, "Говорять юристи" тощо. Тематичними планами лекторію передбачалися цикли лекцій 3 юридичною спрямованістю, а саме: про демократію та законність; про трудове, кримінальне, цивільне законодавство; про права та обов'язки учнівської молоді та деякі інші.

Зазначимо, що виховний ефект правових лекторіїв багато в чому залежав від методики організацї̈ лекцій: “Щоб викликати справжній інтерес до лекції, слід спиратися на потребу учнів у конкретній правовій інформації, вміло пов' язувати іiі з інтересами та щоденним життям і діяльністю учнів. А для цього треба попередньо ознайомитися 3 аудиторією, виявити правові інтереси школярів", $[7,62]$.

Результати нашого дослідження та власний науковий досвід дозволяє стверджувати, що у досліджуваний період правова культура старшокласників та їхнє правове виховання реалізувалися різноманітними засобами, зокрема технічними. Оснащення тогочасних навчальновиховних закладів технічними засобами навчання було на особливо високому рівні і дозволяло усіляко ілюструвати навчально-виховний процес. Часто такі заняття супроводжувалися демонстрацією кінофільмів, пов'язаних 3 пропагандою законності i діяльності правоохоронних органів. Саме це і спричинило виникнення нової форми правового навчання та виховання школярів - кінолекторію.

Проведення кінолекторію відбувалось за чітким планом: “...перед демонстрацією кінофільму виступав лектор з бесідою (15-20 хвилин) і розповідав про ті проблеми, які було піднято у фільмі, приєднуючи їх до конкретних питань права. Потім демонструвався художній кінофільм. Згодом два-три короткометражні науково-популярні і документальні фільми, після яких лектор відповідав на запитання, аналізував з точки зору права ситуації, показані на екрані" [5, $23-24]$.

Серед числа художніх фільмів, що зачіпали правові проблеми, у яких розповідалось про складну і відповідальну роботу співробітників правоохоронних органів, і які 3 цікавістю переглядали старшокласники були: “Звинувачуються у вбивстві” (отримав Державну премію), "Три дні Віктора Чернишева", “Калина червона”, “Сільський детектив”, “Без права на помилку”, “Місто прийняло”, “Петрівка, 38”, “Огарьова, 6” та ін. Позитивний вплив мав також перегляд науково-популярних і документальних фільмів 3 правової тематики. Однак тогочасні науковці вказували на їх недостатню кількість [5, 23].

Кінолекторії як правило організовувалися 3 урахуванням інтересів певної аудиторії, найчастіше старшокласників. Так, при кінотеатрах функціонували кінолекторії “Людина і закон” для старшокласників загальноосвітніх шкіл. Щомісячно читалися лекції на різні правові теми, зокрема: "Я - громадянин Радянського Союзу", “Твій робочий день”, “Основи військового законодавства”, “Суд не лише судить”, “Побут не приватна справа”, “Закон про шлюб і сім’ю”, 
“Це і твоя справа, товаришу!". Лекції супроводжувалися кінофільмами (“Навчання i праця взаємопов’язані”, “Я буду солдатом Батьківщини”, “До служби військової готові”, "Репортаж із залу суду”, “Етюд про шлюб”, "Підліток" і ін.) [4, 95 - 96].

Опубліковані результати опитування школярів щодо їхнього ставлення до правових лекторіїв у дослідженні В. Альхіменка показують, що школярам дійсно була цікавою така форма правовиховної роботи, яка спонукала їх до роздумів і пережиття. Ось деякі відповіді учнів: “Лекторій - це цікаво”; “Добре, що разом 3 лекціями показують фільми”; “Раніше я не ходив на лекції - нудно було, зараз не пропускаю жодного сеансу, дізнався багато цікавого" i т. ін. $[1,51]$.

Отже, тогочасні науковці небезпідставно вважали, що “...правильно організований кінолекторій $\epsilon$ ефективним засобом дії на раціональну і емоційну сторони свідомості підлітків. Саме цей подвійний вплив дозволяє ставити перед вихованцями багато питань морального і правового характеру, що накладає відбиток і на їх поведінку” $[3,10]$.

Таким чином, лекторії стали комплексним заходом формування правовиховної культури школярів, дали змогу поєднати різні методи виховання і зробити цю діяльність масовим явищем.

Також однією із ефективних форм виховання стали семінари, на яких, у свою чергу, практикувалося використання різноманітних виховних методів. Старшокласники, як стверджують дослідники, активно брали участь в семінарах, самостійно проводили бесіди, наприклад: “Громадянином бути зобов'язаний”, вивчали важливі постанови партії і уряду, читали i організовували обговорення книг, зокрема Г. Мединського “Честь", "Не опускаючи очей” та ін. За участю педагогів організовувалися i проводилися у школі вечори на правові теми, такі як: “Право і мораль”, “Наш радянський закон”, "Радянська міліція у боротьбі за Радянську владу”, “Героїзм працівників міліціі” тощо [2, 34].

Критичний аналіз практики правового виховання старшокласників упозакласній виховній діяльності у другій половині ХХ століття дозволяє нам стверджувати, що методична база цього процесу була досить досконалою. Вона презентувалася, поруч із традиційними, значною кількістю різноманітних оригінальних форм позакласної виховної діяльності: “Іншими формами правового виховання молоді є вечоризустрічі з працівниками міліції, суду, прокуратури, ветеранами цих органів; конференції на моральноетичні теми з постановкою, приміром, таких тем, як “Чи правильно ти живеш?”, “Я відповідаю за все!”, “Бережи честь змолоду”; різні диспути і вікторини. На базі дитячих бібліотек з підлітками проводяться бесіди, огляди книг, читацькі конференції, літературні ранки і вечори, виставки популярної літератури про нові радянські закони. У палацах піонерів працюють юридичні секції, при районних будинках піонерів - правові школи" [4,178].

У позакласній виховній діяльності досліджуваного періоду широко практикувалися нетрадиційні, нестандартні, оригінальні форми роботи, головною метою яких було створення цікавої, захоплюючої атмосфери, залучення школярів до активної діяльності. Акцентування уваги на колективних творчих справах (у результаті навіть 3'явилася спеціальна технологія I. Іванова) сприяло залученню великої кількості старшокласників до правовиховної діяльності і забезпечувало певний рівень правових знань старшокласників: "Відвідування школи юного юриста, участь в диспутах, обговорення книги, статті, кінофільму з морально-правовим змістом дозволяють не лише поповнити запас правових знань, але і формувати своє ставлення до цих знань. Бо давно відомо, що в суперечці, в обміні думками утверджуються найбільш важливі і суспільно значимі поняття та істини" $[3,12]$.

Зважаючи на тенденцію індивідуалізації правовиховної роботи серед старшокласників у досліджуваний період активно використовується ducnym. Його розглядали одним із шляхів формування правових уявлень, поглядів і переконань. Предметом диспуту, як правило, обирали важливу морально-правову проблему, яка викликала різні судження, пов'язані з пошуком відповідей на запитання, та була цікавою для старшокласників [5, 28].

У процесі диспуту учні вчилися самостійно оцінювати ті чи інші судження, обстоювати свої погляди, аргументувати їх, диспут підтримував певну оптимістичну та активну атмосферу спілкування, формував громадську думку тощо.

Користь від диспуту полягала не лише у тому, що тут змагалися різні погляди і бачення проблем права. Під час дискусії учасники взаємно збагачувалися новими знаннями в галузі права, долали помилки у розумінні певних фактів та явищ. Добре підготовлений диспут, доводять педагоги, сприяє більш тісним контактам педагогів 3 учнями, створюючи додаткові можливості для врахування індивідуальних особливостей учнів при засвоєнні ними матеріалу у галузі права [7, 69]. 
Однак, М. Фіцула стверджує, що у досліджуваний період дисnуm недостатньо використовувався у практиці тогочасної школи: “Та шкода, і сьогодні диспут у школі - надто рідке явище. Окремі вчителі ще живуть багажем учорашнього дня, не розуміють проблем молоді, не бажають перейнятися тим, що хвилює сьогодні хлопців і дівчат, не кажучи вже про те, щоб спільно обговорити складні життєві ситуації, довести свої погляди і позиції, вислухати думки інших. Некомпетентність таких педагогів породжує в них страх вільно обговорювати наболілі питання" [7,69].

Популярною формою пропагування правових знань були вечори запитань $i$ відповідей та тематичні вечори. Зазвичай вони проводились під певними девізами або назвами: “Жити, відповідаючи за все”, “Твій громадянський обов’язок”, “Закон є закон” і т. ін.

3 метою удосконалення таких форм роботи науковці радили урізноманітнювати методи i засоби впливу на школярів, використовуючи при цьому: виступи працівників суду, прокуратури, міліції, демонструвати кінофільми, виступи колишніх правопорушників.

Ефективною позакласною формою правового виховання старшокласників у другій половині XX століття була екскурсія, в ході якої теоретичні положення наочно підкріплювались практичним матеріалом.

Великий пізнавальний і виховний ефект давали, наприклад, екскурсії у виконком Ради народних депутатів, де можна було конкретно познайомити старшокласників із змістом роботи місцевих органів державної влади. Під час цієї екскурсії учні дізнавалися, як задовольняються матеріальні та духовні потреби населення міста (району, селища, села), які плани його соціального та культурного розвитку на найближчий час.

Чималий пізнавальний і виховний ефект мали екскурсії на підприємства. Вони відрізнялись від екскурсій, що проводились з метою професійної орієнтації. Вони допомагали розширити можливості школи у формуванні в учнів комуністичного ставлення до трудової діяльності, в швидшому придбанні навичок до праці. Педагоги позитивно оцінювали вплив такої форми виховання старшокласників і вважали іiі однією 3 ефективних серед позакласних засобів впливу на правосвідомість школярів.

Варто також звернути увагу й на те, що на наступних етапах розвитку та вдосконалення правового виховання учнів загальноосвітніх навчальних закладів постало питання про доцільність проведення шкільної екскурсії до судової зони. Зокрема, А. Тарас зазначав, що присутність школярів на цьому процесі має для них велике виховне значення, а саме: “...ддозволяє учням познайомитись із практикою роботи народного суду, слугує уроком громадянськості, вчить поважати діюче законодавство, сприяє кращому засвоєнню законів, оскільки “...процес суду - це найкраща, конкретна агітація, яку ніде у практичному житті не можна так добре агітувати, як на судових процесах" $[6,25]$.

Разом із тим, не можна не враховувати, що сама процедура такого процесу, оточення й умови судового слухання можуть справити на школяра сильний емоційний вплив, викликати неправильні оцінки, негативні уявлення. Тому рішення про використання цієї форми правового виховання повинне бути добре продуманим. Виходячи 3 цього, потрібно знайомити учнів лише $з$ тими процесами, організація та проведення яких відповідають ряду умов: близькість справи, що розглядається, до життя неповнолітніх; ії моральне значення; зразкова організація процесу; проведення його досвідченим суддею.

Загальною тенденцією правового виховання старшокласників у виховній роботі школи досліджуваного періоду було залучення школярів до діяльності. Особливо масовими у 1950 1985 рр. були правоохоронні загони, які створювалися зі старшокласників та учнів ПТУ (від 14 до 18 років). Члени цих загонів надавали велику допомогу інспекціям у справах неповнолітніх, народним дружинам, брали активну участь у рейдах із запобігання бездоглядності, бешкетування та правопорушень із боку своїх однолітків, підтримували суспільний порядок у дитячих кінотеатрах, за місцем проживання, залучалися до роботи з перевиховання "тяжких" підлітків. Як свідчать архівні дані [архів], “у результаті цієї правовиховної роботи у школі за останні роки немає правопорушень".

Із метою виховання в підлітків громадянськості, мужності, організовувалися і юнацькі добровільні пожежні дружини. Їх завданням було проведення роботи 3 попередження пожеж, надання допомоги дорослому населенню при гасінні пожеж, першої допомоги постраждалим. Членами дружин могли бути діти від 10 до 17 років.

Варто підкреслити, що вказані загони мали свою структуру, символіку, форму одягу, ритуали, традиції, організовувалися за принципом самоуправління. Керували цими загонами вчителі, організатори позакласної та позашкільної роботи, дільничні інспектори, вихователі дитячих кімнат міліції, суспільні вихователі 3 числа військовослужбовців, ветерани міліції [6, 46 - 57]. 
У багатьох школах створювалися гуртки “Юний юрист”, де досвідчені юристи читали лекції, проводили семінарські заняття, організовували дискусії та обговорення актуальних правових питань, відбувався перегляд кінофільмів на правову тематику та відбувалося обговорення реальних питань. Старшокласники працювали над рефератами, організовували тематичні вечори, виставки, виступали 3 творчими звітами, допомагали працівникам правовиховних органів у справах неповнолітніх, працювали 3 важковиховуваними учнями, випускали бюлетені i стінгазети, організовували конкурси й вікторини [7, 74 - 75]. Усе це сприяло створенню сприятливого ділового клімату у колективі старшокласників, допомагало реально засвоїти правовиховні норми суспільного життя та сформувати вміння використовувати їх у щоденному житті.

Висновки. Багатий арсенал форм, на нашу думку, сприяв ефективній реалізації правового виховання учнівської молоді у II половині XX століття, і дає можливості їх творчого використання в сучасних умовах загальноосвітньої школи.

\section{ЛІТЕРАТУРА}

1. Алексеев С. С. Право и наша жизнь. Москва, 1978. $30 \mathrm{c.}$

2. Давыдов Г. П., Обухов В. М. Правовое воспитание в системе работы школы. Москва, $1976.48 \mathrm{c}$.
3. Найбич В. И. Методика правового воспитания молодежи. Ленинград, 1977. 184 с.

4. Павлов А. С. Правовое воспитание. Москва, $1972.270 \mathrm{c}$

5. Правовое воспитание старшеклассников : методические рекомендации. Минск, 1985. 50 с.

6. ТарасА. Е.Правовоевоспитаниестаршеклассников. Минск, $1988.72 \mathrm{c}$.

7. Фіцула М. М. Правове виховання учнів. Київ, 1997.148 c.

\section{REFERENCES}

1. Alekseyev, S.S. (1978). Pravo i nasha zhyzn [Law and our life]. Moscow, 30 p. [in Russian].

2. Davydov, H.P. \& Obukhov, V.M. (1976). Pravovoye vospitaniye $v$ sisteme raboty shkoly [Legal education in the system of school work]. Moscow, 48 p. [in Russian].

3. Naibich, V.I. (1977). Metodika pravovoho vospitaniya molodezhi [Methods of legal education of youth]. Leningrad, 184 p. [in Russian].

4. Pavlov, A.S. (1972). Pravovoye vospitaniye [Legal education]. Moscow, 270 p. [in Russian].

5. Pravovoye vospitaniye starsheklasnikov: metodicheskie rekomendatsii (1985). [Legal education of senior pupils: methodological recommendations]. Minsk, 50 p. [in Russian].

6. Taras, A.E. Pravovoye vospitaniye starsheklasnikov [Legal education of senior pupils]. Minsk, 72 p. [in Russian].

7. Fitsula, M.M. (1997). Pravove vykhovannya uchniv [Legal education of pupils]. Kyiv, 148 p. [in Ukrainian].

Стаття надійшла до редакції 03.05.2019

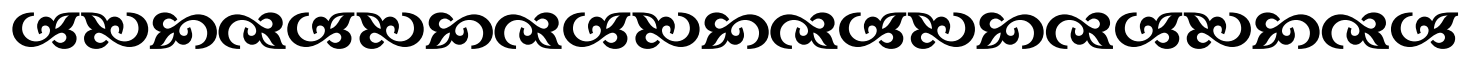

“3 усіх творінь найпреқрасніше - людина, що отримала преқрасне виховання”.

Eniкmem

давньогрецький білособ

“Хочете досягти чогось - помножуйте свої иілі вдвічі".

Невідомий автор

“Фва основні надбання дюдсъкої природи - це розум і мірқування”.

Tisymapx

давньогреиький письменник 3в'язок”.

“Хоча праця і насолода різні за своєю природою, все жміжними є якийсь природний .

Tlium Aiвiü

римський історик

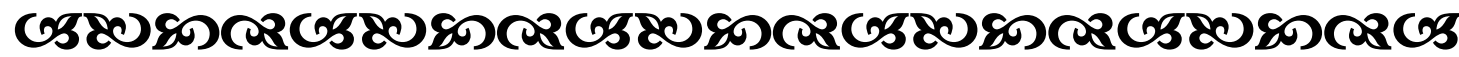

